\section{On love as an (im)properly political concept}

\author{
Eleanor Wilkinson
}

University of Southampton, UK
Environment and Planning D: Society and DOI: I0.I I77/02637758I6658887

epd.sagepub.com

\begin{abstract}
Love has been theorized as a way to rebuild fractured communities, and a potential way to overcome differences on the political Left. However, might it be dangerous to invest so much potential in the power of love? In this paper, I reflect upon Michael Hardt's work on the necessity of love for politics. Hardt emphasizes the radical and transformative potential of love, seeing it as a collective and generative force. Yet, I argue that Hardt's reading of love, tied to a Spinozist theorization of joy, provides a limited understanding of the affective dimensions of love. Instead, I propose that we need to think about the ambivalence and incoherence of love: how love can be both joyful and painful, enduring and transient, expansive and territorial, revolutionary and conservative. That is, to consider how love, even in its seemingly most benevolent and unconditional form, can still be a source of exclusion, violence, and domination. Ultimately, I seek to challenge this fantasy of coherence and togetherness, asking if there is still space for aspects of politics that are not joyful, that do not feel like love, that anger us, disappoint us, and that make us desire distance rather than togetherness.
\end{abstract}

\title{
Keywords
}

Feminism, politics, affect, commons, identity, multitude

Michael Hardt and Antonio Negri's trio of works Empire (2000), Multitude (2005), and Commonwealth (2009) emerged at a time when a number of authors were seeking to combat the then supposed melancholic state of the Left (Brown, 1999; Montag, 2005). Some have even proposed that their first book, Empire, could be defined as a Communist Manifesto for the 21st century (Žižek, 2001). Their work has been widely acclaimed as offering a framework for understanding new forms of global uprising. Central to Hardt and Negri's work is the concept of "the multitude," a mass of people united in opposition to the global capitalist empire. Hardt and Negri propose that love is a key force that can help us release the political potential of this multitude. Love, they argue, is a generative power that enables people to form alliances across alterity, allowing us to create political goals in common. Love is a vital part of the political project of the multitude as it offers the possibility for self-governance and collective transformation. Hardt and Negri (2005: 352, 356)

Corresponding author:

Eleanor Wilkinson, Geography \& Environment, University of Southampton, Southampton, SOI7 IBJ, UK.

Email: e.k.wilkinson@soton.ac.uk 
thus propose that the politics of the multitude can be understood as love, claiming that the "creation of a new humanity is the ultimate act of love," and that "without this love, we are nothing." Love is seen as something that can exist outside of the grasp of Empire, as a force that will help us create new imaginaries and envision new social worlds.

Love has always been a part of Hardt and Negri's writings, but often as a subtext rather than the focal point of their political manifesto. However, in his more recent solo-authored work, Hardt has begun to further theorize the ways in which love could be understood as central to the politics of the multitude. Hardt (2011: 676) has developed some key pillars for a research agenda that he claims will enable us to rediscover a "properly political" concept of love. Hardt recognizes that the concept of love has a complex and politically sensitive history. However, rather than abandon the concept of love, Hardt (2007: np) suggests that "we should still insist of it," as "love has a great heritage worth fighting over." Hardt's premise is that love has been destroyed and corrupted as a political concept, and his aim is to help us rediscover and redefine the political potentials of love.

In this paper I reflect upon some of the potential perils of acting out a transformative political project in the name of love, questioning whether it might be dangerous to invest so much in the power of love. Cindy Patton (1998: 370) for example, writes that she "can't quite bring [herself] to formulate or advocate a new politics of love... [1] ove is too dangerous a basis for social politics." The main question that I am seeking to explore in this paper is whether this new form of political love, intended to embrace the other, inadvertently creates new forms of othering? In short, does a vision of love across difference exclude those who are not invested in this fantasy of togetherness. If good politics is founded upon love and unity then what space is there for anger, fear, and separation? Thus, when discussing the political potentials of love, we must always take into account both "the standpoint of the subordinated" (Jaggar, 1989: 168) and the "politics of location" (Rich, 1986). It is vital to question who is defining the parameters of what makes love political, and to examine how others may perceive love in very different ways. ${ }^{1}$ Accordingly, the paper draws upon a number of feminist, queer, and critical race scholars in order to question Hardt's vision for a "properly political" concept of love.

Ultimately, I suggest that love may indeed be an important concept when seeking to understand political movements. However, the vision of love I outline here is not the positive joyful love found in Hardt's work. Rather, I develop an "improperly political" concept of love - one that recognizes the inextricable relationship between power and domination, between potentia and potestas. Drawing upon Alison Jaggar's (1989: 168) notion of "outlaw emotions," the paper outlines why it is necessary to include the "bad" affective dimensions of love. My aim is thus to develop an understanding of love that identifies how love - even in its most charitable and benevolent form-can still be a source of power, domination, and exclusion. I propose that we need to think about the ambivalence, incoherence, and unruliness of love: how love can be both joyful and painful, enduring and transient, expansive and territorial.

\section{Don't talk to me about love}

To begin, it is important to briefly outline what Hardt means when he talks about love. Why is "love" the term that Hardt chooses to draw upon? Why not solidarity, friendship, or allyship? What is it about love that Hardt feels has such political potential? Of interest here is the way in which Hardt positions political love against other forms of love. For example, he argues that friendship is not a strong enough form of love to guide the politics of the multitude. Hardt claims that "[l]ove in contrast to friendship, involves transformation, in 
other words we lose ourselves in love, or in love we become different," friendship does not have "that transformative capacity" (2007: np). Yet, using insights from certain "standpoints of the subordinated," we could challenge this placing of friendship as somehow a form of light touch intimacy, one that does not have transformative potential (Wilkinson \& Bell, 2012). We could turn to a number of critical works about the politics of friendship and its role in challenging patriarchal domination, racism, homophobia, and in helping create other worlds (Faderman, 1981; Friedman, 1989; Foucault, 1981; Gandhi, 2005; Hesford, 2009; Roach, 2012). Likewise, Hardt (2007: np) dismisses solidarity as another potential alternative, claiming that love in comparison "extends beyond the rational calculus of interests."

Hardt thus proposes that we need to reclaim love from its current narrow definitions in order to redefine and rediscover a truly political concept of love. Hardt (2011: 678) claims that a political understanding of love would be characterized by at least the following three qualities. Firstly, Hardt (2011: 678) thinks that political love must "extend across social scales and create bonds that are at once intimate and social, destroying conventional divisions between public and private." Here, Hardt is arguing that we need to see love as not merely as something that exists in the private sphere. He seeks to challenge the ways in which love has been narrowly confined to the couple form, and argues that we need a more expansive definition of love, one that ventures outside our usual maps of loyalty and affect. Some feminists would no doubt express some affinity with this view, but would question if this newly political understanding of love is really that new. ${ }^{2}$ The positioning of romantic coupled love and familial love as the highest forms of love has been a key source of contestation in much feminist writing and activism (Comer, 1974; Evans, 2003; Jackson, 1993; Jónasdóttir and Ferguson, 2013; Wilkinson, 2012). Many feminist authors have, for example, explored the politics of friendship, solidarity, and sisterhood (Ferguson, 2013; Hesford, 2009; hooks, 1986, 2000; Jackson and Scott, 2004; Jordan, 1978; Lorde, 1984; Nash, 2013; Walker, 1983). Thus, we may wish to ask exactly who is the audience for Hardt's address, as for many feminist theorists and activists, the terrain of love has always been considered a vital site of collective transformation.

Secondly, Hardt argues that political love "would have to operate in a field of multiplicity and function through not unification, but the encounter and interaction of differences" (2011: 678). Here, Hardt is rejecting any romanticized notion of love as fusion, in which two become one. So Hardt's political concept of love is not about becoming unified, however it is, in some ways about becoming different. Thus, Hardt's final and third point is that "a political love must transform us... it must designate a becoming such that in love, in our encounter with others we constantly become different" (Hardt, 2011: 678). Yet this political love is not just about a temporary transformation, for Hardt this vision of revolutionary love is about duration, about creating lasting change: "we always lose ourselves in love, but we lose ourselves in love in the way that has a duration, and is not simply rupture" (Hardt, cited in Davis and Sarlin, 2011: np), "love constitutes powerful bonds that last" (Hardt, 2011: 676).

Here, one might ask who the "we" is in the above quotation - do we always lose ourselves in love? Hardt (2011: 678) claims that "love is thus always a risk in which we abandon some of our attachments to this world in the hope of creating another, better one." Yet, here Hardt fails to grasp the ways in which some bodies cannot risk losing themselves in love, to do so would be too dangerous, we cannot risk losing ourselves in love when we are still finding ourselves. Many people are not seeking transformation; they are seeking survival. Some bodies have endured too long, or have loved too much. For them, love is not about joy or transformation, but about control, power, and oppression. Our subject positions and histories will define whether we will want to embrace this politics of love. What Hardt 
fails to address then, is the limits to how far we can take this love for difference before it falls into love for servitude, or love for our oppressors. For as Lauren Berlant (2012: np) notes, at times "love wounds so badly that all you can do is walk away."

The rest of this paper is divided into three sections, which expand upon some of Hardt's key ideas about love. The first section focuses specifically on the idea that political love should only be about love for difference. I then move on to discuss the importance of positionalities and the standpoint of the subordinated, and how this may affect how we understand the politics of love. Finally, I consider the importance of the politics of bad affect and the unruly "improper" side to love.

\section{Fall in love, fall in line}

In Hardt's theory, different forms of love are placed into hierarchies, where only one kind of love is seen as having political potential. Hardt argues that although love has been commercialized and domesticated, it has never been fully captured by the capitalist empire. Certain forms of love can work as a transformative force, and for Hardt, love is a key way for non-sovereign subjects to create a deliberative democracy. In this section, I pay particular attention to the ways in which Hardt's attempt to formulate a "properly political" concept of love creates a division between "good love" and "bad love." Of interest here are the different spatialities of these two forms of love-the ways good love is seen as expansive, crossing borders, whereas bad love is seen as narrow, parochial, and about desiring sameness. In short, good love is transformative, open to difference, a generative force, and a site of collective transformation. Bad love is closed, reactionary, narcissistic, and tied to love for the same. What Hardt (2007: np) argues, is that love has been corrupted, mainly by the ideal of "love of the same." "Love of the same" has resulted in many forms of discriminatory and hateful political projects. For example, nationalistic and racist groups often claim that their politics is a form of love: love for the Aryan race or love of the nation (see Ahmed, 2003). For Hardt, the dangerous ways that love is so often used in politics can be overcome by founding our political projects not on love for the same, but on a love of difference. So Hardt is arguing that certain kinds of love might act as a mobilizing force for political action and social change, whereas other forms of love can only ever create reactionary and exclusionary forms of politics.

This understanding of political love leads Hardt to dismiss identity-based politics (such as those based around race, gender, and sexuality) as a form of "bad love," claiming that:

The progressive function of any political project animated by the love of the same and unification, even when conducted by or in the name of a subordinated identity, is very limited and constantly runs the danger of becoming reactionary. (Hardt, 2011: 681)

For Hardt, identity politics represent a potentially dangerous and divisive form of politics. This conceptualization of identity politics blames the fractures of the left on those who are suffering, rather than the wider community who are complicit in that suffering. Identity politics is portrayed here as a form of "wounded attachment," whereby identity politics are based upon a shared experience of injustice (Brown, 1995). It is argued that this shared sense of injustice leads to a reactionary and divisive form of politics, and that it stops groups from creating affective ties across difference (Fisher, 2013; Hobsbawm, 1996). Therefore, for Hardt, identity politics potentially holds us back from the wider political goal of the multitude. Identity politics stands in the way of the love of difference, of finding common ground. Yet, there seems to be a profound contradiction here-the multitude 
loves difference, however, we can not possibly love those who love sameness. For Hardt, identity politics is founded on the love of sameness and is therefore a naïve position to adopt: it is dangerous, limited, and runs the danger of becoming reactionary. Hardt portrays identity politics as not really political at all. Yet, here it seems that a politics based on love for difference runs an equal risk of becoming reactionary, when a love of difference becomes a way to exclude the love of the same.

There are significant issues here in the way Hardt theorizes identity politics as being founded solely upon the love of sameness. Hardt's understanding of identity politics ignores the way love functions in identity-based movements. Many authors and activists have emphasized the necessity of identity-based politics for liberatory struggles. They have highlighted that identity politics is not divisive, but instead is an expansive force that opens up the possibility for multiple forms of engagement across difference (Bramen, 2002; Werbner, 1992). For example, Jennifer Nash's (2013) work traces the long history of black feminist activism and the mobilization of love (Collins, 2004; Combahee River Collective, 1983; hooks, 2000; Jordan, 1978), outlining the complex ways in which love is utilized in these political movements. Nash highlights how black feminist activism has never just been about love of the same, noting how "love-politics" is "a practice of the self and a non-identitarian strategy for constructing political communities" (Nash, 2013: 1). Thus, Hardt has overlooked the ways in which identity politics can be about both selfactualization, and a way of transcending the self, as a way to imagine "relationality" "outside of the elisions of identity politics" (Nash, 2013: 5; see also Merla-Watson, 2014 for a similar discussion about the role of love in Chicana feminism).

Another form of "bad love" dismissed by Hardt (2007) is self-love. Self-love, like identity politics, is depicted as a form of narcissism, individualized, apolitical, even anti-political. Selflove is understood as a version of "love of the same" and it is therefore seen to narrow down our political affinities and imaginaries. Yet many feminist, queer, and critical race scholars have demonstrated the ways in which self-love is often a vital source of survival. Not only that, but self-love has also been understood as a necessary pre-condition for love across difference (Anzaldúa, 1988; Jordan, 1978; Springer, 2014; Walker, 1983). Without self-love, certain bodies would not be able to ever become part of the multitude, without self-love certain bodies could not survive. Here, we could turn to Cathryn Josefina Merla-Watson's (2012) critical and important reading of Hardt and Negri's portrayal of love across difference. Merla-Watson draws upon the work of Chicana third space feminists to highlight the limits to Hardt and Negri's metaphors for finding common ground. Of particular interest here is the work of Gloria Anzaldúa (1988) and her metaphor of "bridging." What Anzaldúa provides is a theory about creating connections across difference whilst managing to recognize complex histories of oppression. Anzaldúa's metaphor of a "drawbridge" is important: the drawbridge can be opened when we want to forge connections, but can also be withdrawn at any point. This act of withdrawal recognizes the need for safe space, and acknowledges that attempts to create connections across difference can often be a painful and dangerous task for oppressed groups. Anzaldúa ([1988] 2009: 148) describes drawing up the bridge as a form of self-love, as a way to "nourish ourselves before wading back to the frontlines." For Anzaldúa, self-love is a vital foundation for the formation of coalitional politics and love across difference. Likewise, as June Jordan, notes, "a steady-state deep caring and respect for every other human being... can only derive from a secure and positive self-love" (Jordan, 1978 [2003]: 272).

Ultimately then, I propose that these forms of so-called "bad love" should not be theorized as in conflict with "good-love." We must instead recognize the absolutely crucial politial role of both self-love and identity politics, especially for those who have 
spent their lives oppressed, excluded, silenced, and subject to violence. Self-love and identity politics are not narcissistic distractions, they are lifelines. Yet, what happens in Hardt's definition of "bad love" is that many different kinds of "love for the same" are grouped together-nationalistic love is classified alongside the identity politics of subordinated groups. Yet, nationalistic love-for-the same often works in support of the global capitalist empire, whereas the politics of subaltern groups are fragile, constantly under threat, and a vital part of creating a more just and liveable world. How loving is it to not take into consideration the pain, trauma, and anger that makes self-love and identity politics a vital part of social justice? Thus, we must have a theory of political love that can differentiate between these different forms of love, and that can take into consideration the wider social body in which these bodies operate. The following section continues this discussion, emphasizing the need to take into consideration subordinated voices when trying to formulate a political agenda around love.

\section{And I'm feeling good? Love as collective joy}

Hardt's turn to love is driven by a desire to move away from a traditional ascetic form of politics based on redistribution and sacrifice. Instead, Hardt wants people to embrace a more playful, pleasurable form of politics. Drawing inspiration from early queer activist groups such as ACT UP, Hardt depicts the politics of the multitude as a carnivalesque joyful form of politics. Undoubtedly, defining the politics of the multitude as joyful increases its appeal. Yet might there also be dangers to this strategy? Does this optimistic portrayal raise our expectations about what politics should be, and hence increases our disillusionment when the reality of these movements is often far from joyful? As I have argued elsewhere, these grand narratives about collective joy and commonality can be incredibly alienating and dangerous for marginalized and oppressed groups (Wilkinson, 2009). Particularly for those who may hope that the Left is now feminist, anti-racist, queer-friendly, and who then feel deflated, or even exploited, when they encounter moments where the rhetoric does not match the reality.

Hardt explains that his theoretical move towards a politics of love started:

... with a recognition that in certain political actions, in certain political demonstrations - the really good ones - you do have a feeling of something really like love. And so, it's partly a way of trying to theorize that recognition of this feeling of ... let's call it a 'collective transformation' that one experiences in certain kinds of political action. (Hardt cited in Schwartz 2009: 812)

What does it mean to describe political protest as a feeling "a lot like love"? Firstly, there is an assumption that all subjects involved in these demonstrations experience a feeling of love, and therefore that what Hardt feels is somehow universal, an example of what Adrienne Rich terms, "the arrogance of believing ourselves at the centre" (1986: 223). Secondly, it presumes we all have a shared cultural repertoire - that we can understand what is meant by this thing that feels "a lot like love." As many feminist writers have outlined, there is not necessarily a shared language when it comes to love. For as Julia Kristeva (1987) observes, when one person says "love" it may not be understood or felt in the same way by another. Thus, it is important to take into consideration the multitude of ways in which we might understand love. What if the encounters that you perceive as joyful are experienced as sadness by others?

Furthermore, Hardt's understanding of politics as love is built on the idea that there is a certain kind of affective community created through political action. However, as Sara 
Ahmed (2003: 32) notes, it is by "'having' the right emotion that allows one to pass into the community", "by displaying 'my love', I show that I am 'with you"'. Hardt's understanding of 'politics as love' thus evokes a certain kind of affective register necessary for good politics, which overlooks the other ways people might feel when taking part in political action. What if we do not always feel this joyous love, what happens if certain aspects of the politics of the multitude disappoint us, repel us, anger us, cause us frustration, sideline or oppress us? What space is there for aspects of politics that are not joyful, that do not feel like love, and that make us desire distance rather than togetherness? For as Ahmed (2007: 132) states, what makes a scenario seem "happy" is often "in part what it conceals or keeps from view."

In this section, like Hardt, I draw upon personal experience, and I do so in order to demonstrate how similar events can be felt differently, and to think about whether the ideal of "politics as love" sometimes shuts down alternative affective states.

\section{Rumination}

We are at an anti-cuts demo in central London. Crowds have always made me nervous, a feeling that something may go wrong at any moment. But this is what you have to do, take yourself to the street, overcome your fears, take action. So here we are on a cold winter's day in London. I look around, it's diverse; there are all sorts of different groups gathering. From environmental activists, socialist workers, hard-line old Labour, disability groups, NHS workers, anti-cuts activists, and a wide range of different groups from a younger generation of activists. "Perhaps this is it? Perhaps this is the multitude in action," I think. Coming together with a multiple but singular voice, uniting in our differences to challenge the neoliberal retrenchment of the welfare state. Perhaps this is it. We gather by a building where a prominent Conservative MP is due to be speaking. The atmosphere is carnivalesque. Some people play instruments, others sing. I look across to see a group of young teenage boys in infamous Anonymous masks - chanting a song about the Zapitismo movement. I feel uncomfortable with this cultural appropriation but I let it slip, this is not a day for over-analyzing, we are meant to be joyful, feeling the power of this collective force. Another group unravels a banner, the Prime Minister's name followed by a derogative misogynistic word. One of the women in the group of disability activists shouts out, "take that down, now, it's disgusting." A woman by her side joins in, and others begin to call out. Then the younger men with the banner shout back "what's your problem, it's just a word!" The argument continues and gradually gets more heated. An older male intervenes to defend the banner "What's your problem? They're not the enemy, it's that lot in there that are" (he says gesturing to the building where the politicians are). Things calm down, the incident ends.

What can we infer from this experience? Is it just a one-off minor occurrence that we should not dwell upon? Yet there are numerous examples of masculinism, sexism, racism, and homophobia within current Leftist politics (Campbell, 2011; Habiba, 2011; Halvorsen 2014; Juris et al., 2012; Kilibarda, 2012; McVeigh, 2011; Merla-Watson, 2014). I want to think through whether a belief in "politics as love" may in fact limit how we can respond to such incidents. Does "politics as love" create a framework where instances such as these are seen as a failure of love? Or at worst, do these occurrences get framed as a diversion, a distraction from the real goal of the multitude? If we are supposed to be joyful and loving, then do these incidents get swept aside? Love may make us overlook things, because we want so desperately to believe in the power of love, because we want to make this relationship 
work. This compulsion to love could at times make us endure things we should not have to endure. If the fantasy of a coherent joyful loving multitude is the object of our love, we might become hostile when we feel our object of love is under threat. Calling out injustice in these spaces endangers the fantasy of joyful togetherness. Moreover, as I shall go on to explore further in the next section, this incident highlights how a desire for a joyful and loving multitude provides a limited understanding of the affective life of political protest. What was political in the above rumination, was it the temporary feeling of collective joy, or was it the friction, the challenge, the anger? $?^{3}$ I propose that it was not the joyful aspects of politics that were teaching the multitude self-governance, but the moment when this joyful veneer broke down. "Bad" affects, I would argue, are hence crucial to any political project that seeks to bring people together across difference.

\section{Bad affects}

Hardt draws upon Spinoza in an attempt to bring the body back into political theorizing, in order to pay attention to the affective dimensions of political life. Affects, for Spinoza, are the means "by which the body's power of acting is increased or diminished" (Spinoza, 1985: EIII, P3). Spinoza argues that each different affect or passion may increase or decrease our power to act. Spinoza terms the affects that increase a body's power to act joy (laiefta). Other forms of passion, such as sadness and fear, are seen to decrease our capacity to act; these passions hinder and restrain the body. Hardt claims that his understanding of love derives from Spinoza's (EIII, P13) declaration that "love is joy with an external cause." The aim of the multitude is to think about how bodies can come together to increase their collective potential, increasing our power to affect and be affected.

Hardt's political concept of love is an attempt to move beyond an individualistic approach to understanding affective encounters within the political body; his Spinozist approach is inherently relational. Hardt is attempting to think affect beyond subjectivity, and to instead focus on the potentia that emerges when bodies come together. Yet, this fails to address the uneven terrain on which bodies encounter each other to begin with. For, as Ahmed (2004) notes, affect cannot be separated from issues of power, privilege, and oppression. Ahmed traces how affect circulates in particular ways, with certain bodies accused of getting in the way of collective happiness, of creating "bad affect." We see this at work when we look at Hardt's dismissal of identity politics as "bad love," and the way certain bodies have been depicted as responsible for decreasing our capacity to act, as holding back the collective force of the multitude.

Thus, what is lacking in Hardt's attempt to reclaim love as a political concept is a full consideration of exactly who these lovers are, and the "cartographies of power" through which these encounters take place (Braidotti, 2001; see also Merla-Watson, 2014). What I have been arguing throughout this paper then, is that any theory of love in the multitude must take into account how traces of our encounters with other bodies alter the way we understand and feel love. For example, encounters with systemic racism, or patriarchy, will alter the way in which we are affected (see Ahmed, 2006). Yet, Spinoza's work does in fact allow for an understanding of the unequal power relations that affect an encounter. Spinoza sees bodies not as singular entities but as part of a social body. All bodies are affected differently depending on their composition and their histories. Thus, the way a body will be affected is dependent on its position within the social body. For, as Spinoza notes, the capacity to be affected will "involve the nature of the human body and at the same time the nature of the external body" (EII P16). It is this aspect of Spinoza's understanding of 
affective encounters that remains under-examined in Hardt's proposals for a "properly political" concept of love.

Throughout this paper, I have read Hardt's theorizations about "love as joy" through a number of different subordinated positionalities. Drawing on Jaggar's work around the "standpoint of the subordinated" and Rich's (1986) notion of "the politics of location" I have highlighted how the fantasy of "good love" may not be shared by all, and have instead traced how this creation of a joyful loving multitude may in fact exclude or repel certain bodies. Our positionalities and histories will shape our desire to fall in love with these political fantasies of collective joy. In this section, continuing this discussion about the "standpoint of the subordinated," I want to dwell on the potentials of "bad" affect. As previously outlined, Hardt's understanding of the politics of love as "collective joy" creates a repertoire of "outlaw emotions" that are seen to have no place in the affective political life of the multitude. Therefore, does a focus on collective joy paper over issues of injustice within the multitude? In order to think through the importance of "bad" affect it is necessary to revisit two terms that are central to Hardt's understanding of the politics of love: Spinoza's concepts of potentia and conatus.

Hardt presumes that a loving encounter across difference will expand our power, and increase our collective potentia. Yet here Hardt fails to fully consider how a seemingly loving encounter across difference may in fact diminish our potentia, or lead to our eventual selfdestruction. Here, we could turn to feminist work around oppression and love, and how a "love for love" has often resulted in women becoming lovingly attached to the very conditions of their own subordination (Bartky, 1990; Langford, 1999). Love is not something that necessarily increases our capacity to act; it may also be something that can decrease our potentia. As Bernice Johnson Reagon notes in her work on black feminist coalition building, forming a coalition is rarely a joyful encounter. As she states,

You don't go into coalition because you just like it. The only reason you would consider trying to team up with somebody who could possibly kill you, is because that's the only way you can figure you can stay alive. (1983: 343-344)

Loving across difference is dangerous work, it is not about joy, coalitions can kill. The weight of the burden of coalitional politics is not something we should necessarily have to bear. If a coalition or encounter decreases our capacity to act then we should refuse to engage.

Thus, greater consideration needs to be given to the relation between domination and love, and how our power can be diminished in encounters across difference, even if this encounter speaks the name of unconditional love. Spinoza's account is attentive to the different power relations at play when bodies encounter one another, recognizing the way in which a bodies' integrity may be destroyed if it enters into an encounter with another more powerful body (see Gatens, 1996). Yet, these complex geometries of power are given scant attention in Hardt's theorizations. A person's potentia might be increased by not entering into an encounter with the multitude to begin with. The key to our self-preservation might be found instead in the socalled "bad" love-of-the-same that can be found in certain strands of identity politics.

At one point when discussing the politics of love Hardt (cited in Hardt et al. 2004: np) claims that the politics of the multitude is a "collective project for the increase of joy." Yet, I propose that the politics of the multitude cannot, and should not, be solely a project of collective joy. To frame political life in this way runs the risk of devaluing the importance of encounters that are far from joyful. What then of anger, of pain, of shame or of guilt? (see Hemmings, 2012; Holmes, 2004; Love, 2007; Ngai, 2009; Probyn, 2005; Wilkinson, 2009). 
What role might these play in understanding the affective life of the multitude? As I shall go on to outline, the encounters that produce "bad" affects are just as politically important as those that bring us joy. Furthermore, as Sue Ruddick (2010: 26) notes:

The desire to avoid painful encounters might well lead us to steer clear of associations whose discomfort arises, in fact, from a social field that reinforces racism, sexism, class bias or other forms of oppression. How, then, do we traverse the uncomfortable divide presented by difference as alterity?

Ruddick raises a significant concern here, that a drive for politics as collective joy may mean we overlook the role of discomfort and its necessity for political movements that are seeking to challenge oppression and injustice.

This desire to "avoid painful encounters" is exemplified by Hardt's statement (cited in Hardt et al. 2004: np statement that "to make the world better, I don't need to give up things, I need to gain things. I need to gain a more joyful life." Contrary to Hardt, I propose that some people may in fact need to gain a less joyful life. That rather than feeling collective joy, some should in fact be feeling shame, sorrow, and humility when encountering others. Reaching out across difference should not always feel joyful. Derrida (1999: 70), for example, is attentive to the way in which unconditional hospitality can be a deeply painful experience, as it requires "that you give up mastery of your space, your home, your nation. It is unbearable." Hence, for certain bodies in the multitude (those with relative power and privilege, those who have always had a voice, those who have had always had space), we should instead be thinking of ways in which their potentia may need to be diminished. Perhaps some bodies have already been too joyful and too powerful, perhaps some bodies' potentia should in fact decrease in the hope that others who have been excluded may finally have the space to flourish. Žižek, for example, drawing upon Freud's theorization of the death-drive, revisits Spinoza's notion of conatus - to examine the ways in which the conatus could be "based on a fundamental act of selfsabotaging," rather than on self-preservation (Žižek, 2003: 34). What role might there be in the politics of the multitude for this kind of self-sabotage?

What is required is a fuller examination of the power and hierarchies at work in these encounters across difference. I thus propose that greater consideration needs to be given to the relation between potentia and potestas - and the ways in which "power together" often falls into "power over." Hence the question that remains is how do people enter into relations with one another to increase their collective power, whilst still respecting each other's power? How can we do so in ways where one individual does not capture or exploit the power of the other for their own gain? As outlined earlier, "good love," even its most benevolent form, can still be a way in which we seek to impose our desire upon another; love across difference does not escape domination (Benjamin, 1988; De Beauvoir, 1949).

\section{Conclusion: Just another love story?}

This paper has argued that a narrow conceptualization of "love as joy" limits our understanding of the affective dimensions of political life. In Hardt's theory, different forms of love are placed into hierarchies, where only one kind of love is seen as having transformative potential. However, rather than dividing love into good and bad forms, a truly political understanding of love would recognize the messiness, ambiguities, and unruliness of affective life. That is, to think about the often blurred boundaries between selfless good love and selfish bad love, rather than dividing them into two separate entities (see Nancy, 2003). Love is never only about joy and "good" affects, love has a multitude of 
different affects, and these negative "bad" affects might also be political. Political love is not just about collective joy, but also love as fear, love as disappointment, love as rage, love as domination. Therefore, rather than simply dismissing "bad love" as "not political," we might instead seek to recognize the political dimensions of both "good" and "bad" forms of love. This broader understanding of love would help us stay alert to the ways in which we may enter politics with joyful loving intentions, but the other side of love: domination, control, and oppression are never far away. Might the ambivalence of love allow us to better understand the incoherence of political life? Love rarely produces coherence, yet perhaps the ambiguity and unruliness of love is its most political strength. Yet, Hardt has tamed the unruly aspects of love, shaped them into a conventional romantic plot, and despite adamant claims to the contrary, there are many aspects of this love story that we have heard many times before. So rather than trying to prescribe a "properly" political concept of love, we could instead turn to the "improperness" of love. For as Berlant (2011: 687) notes, in her critique of Hardt's theory of love:

... I would rather begin my thought looking at the whole field of what it takes to sustain an attachment to the world. The ambitions and capacities of love would be magnetized to attachment, but other modes of relating would be too, the ones involving proximity, solidarity, collegiality, friendship, the light touch and intermittent ones, and then the hatreds, aversions, and not caring... I want a bigger imagination of the affective dimensions that it would take to (re)build a world.

If we return to the example of the London protest, the angry moment of contestation was displaced by the unifying language of loving togetherness. Here, it was the supposed "bad affect" of anger (an anger that was, of course, provoked by love) that had the potential to disrupt the order of things and to reach out across difference; however, a desire for loveas-unity meant that this potentially political encounter was shut down. Theorizing love as joy provides a limited understanding of the affective dimensions of political life. When we dismiss the importance of angry forms of love, we uphold existing power hierarchies within the multitude.

Hardt's vision of a revolutionary world of lovers, where we all love one another, and where we all love difference, may seem on first glance a utopian vision which would be positively mean-spirited to oppose. Differences will not be a source of hierarchy, as the multitude loves difference. Instead, we will learn to love differently and "properly," we will learn to love the other in a way that makes these hierarchies collapse. However, it is important to acknowledge the ways in which it might be even harder to see how love, even in its seemingly most benevolent, unconditional, and well-intentioned forms, can still be a form of exclusion. This is not to say that solidarity and love for the Other cannot happen, or that politics is never about joyful forms of love. Simply that we must be aware of the ways in which love for the Other can still mask indifference or hate, and can lead to the creation of a new affective ideal, which others might fail to meet. Love is not just a generative power for good; love can also close down dialogue, narrow our worlds and limit our imaginaries. As feminist critiques of romantic love have long argued, love can often be as much about violence and domination than it is about care and support.

Thus, what if we feel that this rhetoric of political love is just another way to control us and to silence us? What happens when someone in the multitude cannot or will not return this love? However, Hardt would argue that his vision of love is not about the promise of return, as love in the multitude is always unconditional. Yet, what happens when you continue to love us, even though we did not want your love to begin with? Hardt's understanding of the political function of love presumes a willingness from the other to 
enter into this relationship. We will love you, we welcome you-even if you do not want to be a part, even when you want to be apart. What happens when this unconditional love across difference is met with revulsion, irritability, anger, or jaded cynicism? Clearly, these are not the "right" responses, they become "outlaw emotions" (Jaggar, 1989). Thus, despite all the benevolence and good intentions, Hardt's "properly political" concept of love still masks issues of power and domination. Therefore, it is important to challenge this fantasy of joyful coherence and togetherness, we need to question how this fantasy of political love is distributed, and in whose interests it might serve. Ultimately then, this understanding of love, designed to transcend across differences, has actually created new forms of exclusion, and new forms of othering.

\section{Declaration of conflicting interests}

The author(s) declared no potential conflicts of interest with respect to the research, authorship, and/or publication of this article.

\section{Funding}

The author(s) received no financial support for the research, authorship, and/or publication of this article.

\section{Notes}

1. Hawkesworth (2006) has challenged what she terms the "gendered ontology" of the multitude, pointing out the male citational practices of Hardt and Negri's work, and the misappropriation of queer and feminist authors. See also Merla-Watson (2014: 175-176) for a critique of the Eurocentric underpinnings of much of Hardt and Negri's work, and their misreading and misrepresentation of critical race and queer writers.

2. Some feminist writers have challenged the idea that intimate love can be used as a template for political action, with Dietz (1985: 32) arguing that love loses it's "concrete specificity" if applied "to people as a whole or marshalled for political ends."

3. See Maharawal (2011) for an alternative affective archive about the politics of the multitude, focusing on the rage, fear, and exhaustion that comes from challenging white privilege in the Occupy movement.

\section{References}

Ahmed S (2003) In the name of love. Borderlands E-Journal: New Spaces in the Humanities 2(3). Available online at: http://www.borderlands.net.au/vol2no3_2003/ahmed_love.htm.

Ahmed S (2004) The Cultural Politics of Emotion. Edinburgh: Edinburgh University Press.

Ahmed S (2006) Queer Phenomenology: Orientations, Objects, Others. Durham, NC: Duke University Press.

Ahmed S (2007) Multiculturism and the promise of happiness. New Formations 63: 121-136.

Anzaldúa G (2009) [1988] Bridge, Drawbridge, Sandbar, or Island: Lesbians-of Color Hacienda Alianzas. In: Anzaldúa G and Keating A (eds) The Gloria Anzaldúa Reader. Durham: Duke University Press, pp. 140-156.

Bartky SL (1990) Femininity and Domination: Studies in the Phenomenology of Oppression. New York, NY: Routledge.

Benjamin J (1988) The Bonds of Love: Psychoanalysis, Feminism, and the Problem of Domination. New York: Pantheon.

Berlant L (2011) A properly political concept of love: Three approaches in ten pages. Cultural Anthropology 26(4): 683-691. 
Berlant L (2012) The book of love is long and boring, no one can lift the damn thing... Available at: http://supervalentthought.com/2012/06/03/the-book-of-love-is-sad-and-boring-no-one-can-lift-thedamn-thing/ (accessed 27 June 2016).

Braidotti R (2001) Metamorphoses: Towards a Materialist Theory of Becoming. Cambridge, Polity: Polity Press.

Bramen CT (2002) Turning point: Why the academic left hates identity politics. Textual Practice 16(1): $1-11$.

Brown W (1995) States of Injury: Power and Freedom in Late Modernity. Princeton, NJ: Princeton University Press.

Brown W (1999) Resisting left melancholy. Boundary 2 26(3): 19-27.

Campbell ERA (2011) A critique of the occupy movement from a black occupier. The Black Scholar 41(4): 42-51.

Collins PH (2004) Black Sexual Politics: African Americans, Gender, and the New Racism. New York: Routledge.

Combahee River Collective (1983) The Combahee River Collective Statement. In: Smith B (ed) Home Girls: A Black Feminist Anthology. New York: Kitchen Table Press.

Comer L (1974) Wedlocked Women. Leeds, UK: Feminist Books.

Davis H and Sarlin P (2011) No One is Sovereign in Love: A Conversation Between Lauren Berlant and Michael Hardt. amour 18. Available at: http://nomorepotlucks.org/site/no-one-is-sovereignin-lovea-conversation-between-lauren-berlant-and-michael-hardt/.

De Beauvoir S (1949/1978) The Second Sex. Harmondsworth: Penguin.

Derrida J (1999) Hospitality, justice and responsibility: A dialogue with Jacques Derrida. In: Kearney $\mathrm{R}$ and Dooley M (eds) Questioning Ethics: Contemporary Debates in Philosophy. London and New York: Routledge, pp. 65-83.

Dietz MG (1985) Citizenship with a feminist face: The problem with maternal thinking. Political Theory 13(1): 19-37.

Faderman L (1981) Surpassing the Love of Men: Romantic Friendship and Love between Women From the Renaissance to the Present. New York: Morrow.

Ferguson A (2013) Feminist Love Politics: Romance, Care and Solidarity' in Love: A Question for Feminism in the Twenty-First Century. London and New York: Routledge.

Fisher M (2013) Exiting the vampire castle. The North Star. Available online at http://www. thenorthstar.info/?p=11299 (accessed 22 November 2013).

Foucault M (1981/1997) Friendship as a Way of Life. In: Lotringer S (ed.) Foucault Live: Collected Interviews 1961-1984. Cambridge, MA: MIT Press.

Friedman M (1989) Feminism and modern friendship: Dislocating the community. Ethics 99(2): 275-290.

Gandhi L (2005) Affective Communities: Anticolonial Thought, Fin-De-Siècle Radicalism, and the Politics of Friendship. Durham, NC: Duke University Press.

Gatens M (1996) Imaginary Bodies: Ethics, Power and Corporeality. London and New York: Routledge.

Habiba A (2011) How people of color occupy wall street. The Nation, 4th November 2011. Available at www.thenation.com/article/how-people-color-occupy-wall-street/ (accessed 27 June 2016).

Halvorsen S (2014) Taking space: Moments of rupture and everyday life in occupy London. Antipode 47(2): 401-417.

Hardt M (2007) About love. European Graduate School. Available at: www.youtube.com/watch? $\mathrm{v}=$ ioopkoppabI (accessed 27 June 2016).

Hardt M (2011) For love or money. Cultural Anthropology 26(4): 676-682.

Hardt M and Negri A (2000) Empire. Cambridge, MA: Harvard University Press.

Hardt M and Negri A (2005) Multitude: War and Democracy in the Age of Empire. London and New York: Penguin.

Hardt M and Negri A (2009) Commonwealth. Cambridge, MA: Harvard University Press.

Hardt M, Smith C and Minardi E (2004) The collaborator and the multitude: An interview with Michael Hardt. Minnesota Review 61(1): 63-77. 
Hawkesworth M (2006) The gendered ontology of "Multitude". Political Theory 34(3): 357-364.

Hemmings C (2012) Affective solidarity: Feminist reflexivity and political transformation. Feminist Theory 13(2): 147-161.

Hesford V (2009) The politics of love women's liberation and feeling differently. Feminist Theory 10(1): $5-33$.

Hobsbawm E (1996) Identity politics and the left. New Left Review (217): 38-47.

Holmes M (2004) Feeling beyond rules politicizing the sociology of emotion and anger in feminist politics. European Journal of Social Theory 7(2): 209-227.

hooks b (1984) Feminist Theory: From Margin to Center. Cambridge, MA: South End Press.

hooks b (2000) All About Love: New Visions. New York: William Morrow and Company.

Jackson S (1993) Even sociologists fall in love: An exploration in the sociology of emotions. Sociology 27(2): 201-220.

Jackson S and Scott S (2004) The personal is still political: Heterosexuality, feminism and monogamy. Feminism \& Psychology 14(1): 151-157.

Jaggar AM (1989) Love and knowledge: Emotion in feminist epistemology. Inquiry 32(2): 151-176.

Jónasdóttir AG and Ferguson A (2013) Love: a question for feminism in the twenty-first century. London \& New York: Routledge.

Jordan J (1978/1981) Where is the Love? Civil Wars. London: Simon and Schuster.

Juris JS, Ronayne M, Shokooh-Valle F, et al. (2012) Negotiating power and difference within the $99 \%$. Social Movement Studies 11(3-4): 434-440.

Kilibarda K (2012) Lessons from Occupy in Canada: Contesting space, settler consciousness and erasures within the 99\%. Journal of Critical Globalisation Studies 5: 24-41.

Kristeva J (1987) Tales of Love. New York: Columbia University Press.

Langford W (1999) Revolutions of the Heart: Gender, Power and the Delusions of Love. London \& New York: Routledge.

Lorde A (1984) Uses of the erotic: The erotic as power. Sister Outsider: Essays and Speeches. Freedom, CA: The Crossing Press, pp. 53-59.

Love H (2007) Feeling Backward: Loss and the Politics of Queer History. Cambridge, MA: Harvard University Press.

Maharawal MMC (2011) So Real It Hurts- Notes on Occupy Wall Street, Racialicious. Available online at: http://www.racialicious.com/2011/10/03/so-real-it-hurts-notes-on-occupy-wall-street/ (accessed 3 October 2011).

McVeigh K (2011) Occupy Wall Street's women struggle to make their voices heard. The Guardian, 30 November 2011. Available at www.theguardian.com/world/2011/nov/30/occupy-wall-streetwomen-voices (accessed 27 June 2016).

Merla-Watson CJ (2012) Bridging common grounds: Metaphor, multitude, and chicana third space feminism. ACME: An International E-Journal for Critical Geographies 11(3): 492-511.

Merla-Watson CJ (2014) Revolutionary Love: Bridging Differential Terrains of Empire. In: Hernández E and Rodriguez y Gibson E (eds) The Un/Making of Latina/o Citizenship. New York: Palgrave Macmillan, pp. 167-189.

Montag W (2005) Who's Afraid of the Multitude? Between the Individual and the State. South Atlantic Quarterly 104(4): 654-673.

Nancy JL (2003) A Finite Thinking. Redwood City, CA: Stanford University Press.

Nash JC (2013) Practicing love: Black feminism, love-politics, and post-intersectionality. Meridians: Feminism, Race, Transnationalism 11(2): 1-24.

Ngai S (2009) Ugly Feelings. Cambridge, MA: Harvard University Press.

Patton C (1998) 'On Me, Not in Me' locating affect in nationalism after AIDS. Theory, Culture \& Society 15(3): 355-373.

Probyn E (2005) Blush: Faces of Shame. Minneapolis, MN: University of Minnesota Press.

Reagon BJ (1983) Coalition Politics: Turning the Century. In: Smith B (ed.) Home Girls: A Black Feminist Anthology. NewYork: Kitchen Table Press.

Rich A (1986) Notes towards a Politics of Location. Blood, Bread, and Poetry: Selected Prose 19791985. London: W.W Norton. 
Roach T (2012) Friendship as a Way of Life: Foucault, Aids, and the Politics of Shared Estrangement. New York: SUNY Press.

Ruddick S (2010) The politics of affect Spinoza in the work of Negri and Deleuze. Theory, Culture \& Society 27(4): 21-45.

Schwartz L (2009) A conversation with Michael Hardt on the politics of love. Interval(le)s 3(1): $810-821$.

Spinoza B (1985) Collected Works of Spinoza, Vol 1. Princeton, NJ: Princeton University Press.

Springer K (2014) Third wave black feminism? Signs 40(1): 1059-1082.

Walker A (1983) In Search of Our Mothers' Gardens. New York: Harcourt Brace.

Werbner P (1992) Essentialising essentialism, essentialising silence: Ambivalence and multiplicity in the constructions of racism and ethnicity. In: Werbner P and Modood T (eds) Debating Cultural Hybridity: Multi-Cultural Identities and the Politics of Anti-Racism. London: Zed Books, p. 230.

Wilkinson E (2009) The emotions least relevant to politics? Queering autonomous activism. Emotion, Space and Society 2(1): 36-43.

Wilkinson E (2012) The romantic imaginary: Compulsory coupledom and single existence. In: Hines S and Taylor Y (eds) Sexualities: Past Reflections, Future Directions. Basingstoke: Palgrave, Macmillan.

Wilkinson E and Bell D (2012) Ties that blind: On not seeing (or looking) beyond 'the family'. Families, Relationships and Societies 1(3): 423-429.

Žižek S (2001) Have Michael Hardt and Antonio Negri rewritten the Communist Manifesto for the twenty-first century? Rethinking Marxism 13(3-4): 190-191.

Žižek S (2003) Organs without Bodies. London and New York: Routledge.

Eleanor Wilkinson is a feminist geographer whose work explores the intersections between intimacy, culture, and the political economy. She is particularly interested in the geographies of gender and sexualities, late-capitalist transformations of intimate life, feminist utopianism, and critical social theory. Eleanor is currently working on an ESRC-funded research project looking at welfare reform and the regulation of intimate life. 